\title{
Effects of Different Levels of BioAcid Ultra on Growth Performance, Survival, Hematologichal and Biochemical Parameters of Fingerlings Rainbow Trout (Oncorhynchus mykiss)
}

\author{
Mohsen Mohamadi Saei ${ }^{1}$, Kiarash Beiranvand ${ }^{2}$, Hadis Mansouri Taee ${ }^{3}$ and Hamed Nekoubin ${ }^{3 *}$
}

${ }^{1}$ Lorestan Agricultural and Natural Resources Research and Education Center, AREEO, Khorramabad, Iran ${ }^{2}$ Lorestan Fisheries Administration, Khorramabad, Iran

${ }^{3}$ Department of Fisheries, Gorgan University of Agricultural Sciences and Natural Resources, Gorgan, Iran

\begin{abstract}
The aim of the study was to determine the effect of different levels of BioAcid Ultra on growth performance survival, enzymatic activity, hematological and biochemical parameters of fingerlings rainbow trout. For this purpose, 900 fish were stocked in three treatments at the Concrete pools and fed 4 times a day by $0.1 \%$ and $0.2 \%$ of BioAcid Ultra (T1 and T2) for 60 days. After 60 days feeding on the experimental diets, there were no significant difference $(P>0.05)$ was observed in survival of fish. Groups of fish which were fed diet supplemented with $0.1 \%$ and $0.2 \%$ Bio Acid Ultra displayed improved $(P<0.05)$ growth performance, including GBM and SGR. No significant differencein enzymatic activity (Alkaline Phosphatase (ALP), Alanine aminotranferase (ALT) and Asparatate aminotransferase (AST)) and hematological parameters (Red blood cells (RBCs), white blood cells (WBCs), hemoglobin ( $\mathrm{Hb}$ ) and Hematocrit (Hct)) was observed between T1, T2 and control group $(P>0.05)$. No significant difference $(P>0.05)$ in serum Glucose, Triglyceride and TP was observed in treatments and control group. The results of the present study showed a significant $(P<0.05)$ decrease in Globulin in $T 1$, whereas serum albumin was higher in $T 1$ when compare with control group $(P>0.05)$. In the present study, the best performance of fish in terms of growth performance in fingerlings rainbow trout, was recorded at organic acids at a $0.1 \%$ dose.
\end{abstract}

Keywords: BioAcid Ultra; Growth performance; Enzymatic activity; Biochemical; Rainbow trout

\section{Introduction}

Successful production of fish depends on the availability of suitable food that can be caused inhancment of health and growth especially in the larval stage [1]. One of many strategies to improve fish health and performance in aquaculture is by including feed additives such as amino acid, antibiotic and organic acid to produce functional feeds [2]. Use of the antibiotic growth promoters in fish feed improves their growth, feed conversion and survival rate. However, these antibiotics produce resistance in micro-biota of fish that may lead to cross-resistance among human. Consequently, researchers focused on alternative additives such as organic acids, probiotics, herbs, enzymes and essential oils. Among them, short-chain organic acids are of special interest due to their beneficial effects in preservation of feed [3-5].

Organic acids and their salts have been used as feed additives functioning as acidifiers of animal feeds. Such organic acids, including acetic, butyric, citric, formic, lactic, malic, propionic and sorbic acid have been shown to improve health and growth performance in livestock [6]. The beneficial effects of acid-preserved products caught the attention of the scientific community, leading to the investigation of the effects of these short-chain acids in fish feeds. The use of organic acids has been reported to enhance of nutrient utilization, growth performance, digestibility, mineral absorption, alter gut microflora population and increase the disease resistance in aquaculture [7]. The pastive effcts of acidifiers in different species including rainbow trout (Oncorhynchus mykiss) [8], red hybrid tilapia (Oreochromis sp.) [9], rohu (Labeo rohita) [10], yellow catfish (Pelteobagrus fulvidraco) [11], Beluga (Huso huso) [12], and red drum (Sciaenops ocellatus) [13] have been demonstrated.

In animal nutrition, acidifiers exert their effects on performance via different mechanisms. Acidifiers function as conserving agents by reducing the $\mathrm{pH}$ of the feed, thereby inhibiting microbial growth and thus lowering the uptake of possibly pathogenic organisms and their toxic metabolites by the farm animals [14]. They reduce the $\mathrm{pH}$ level in the stomach, particularly in the small intestine, through delivery of $\mathrm{H}^{+}$ions, and on the other hand they inhibit growth of Gram-negative bacteria through the dissociation of the acids and the production of anions in side bacterial cells $[15,16]$. Positive effects of organic acids on protein hydrolysis have been demonstrated [15]. Feed supplementation with organic acids has been shown to lead to lower duodenal $\mathrm{pH}$ improved nitrogen retention and increased nutrient digestibility [16].

Despite the discrepancies among the published data, more research is needed to better understand the potential beneficial effects of these compounds and their mixtures. Therefore, in the present study attempted to investigate the effects of different levels of BioAcid Ultra (Buffer mixture of formic acid, propionic acid and lactic acid) on growth performance, survival, enzymatic activity, hematological and biochemical parameters of fingerling rainbow trout (Oncorhynchus mykiss).

\section{Materials and Methods}

\section{Diet experimental design}

Commercial trout diet as basal diet was purchased from Chineh

*Corresponding author: Hamed Nekoubin, PhD Student, Department of Fisheries Gorgan University of Agricultural Sciences and Natural Resources, Gorgan, Iran Tel: +98 173222 0321; E-mail: nekoubin.hs@gmail.com

Received September 05, 2016; Accepted November 15, 2016; Published November 17, 2016

Citation: Saei MM, Beiranvand K, Taee HM, Nekoubin H (2016) Effects of Differen Levels of BioAcid Ultra on Growth Performance, Survival, Hematologichal and Biochemical Parameters of Fingerlings Rainbow Trout (Oncorhynchus mykiss). J Aquac Res Development 7: 455. doi: 10.4172/2155-9546.1000455

Copyright: ( 2016 Saei MM, et al. This is an open-access article distributed unde the terms of the Creative Commons Attribution License, which permits unrestricted use, distribution, and reproduction in any medium, provided the original author and source are credited. 
Citation: Saei MM, Beiranvand K, Taee HM, Nekoubin H (2016) Effects of Different Levels of BioAcid Ultra on Growth Performance, Survival, Hematologichal and Biochemical Parameters of Fingerlings Rainbow Trout (Oncorhynchus mykiss). J Aquac Res Development 7: 455. doi: 10.4172/2155-9546.1000455

Page 2 of 5

Company, Tehran, Iran. Biochemical analysis of basal diet and treatmen diets showed in Table 1. BioAcid Ultra was purchased from Aria trading company Dallman (exclusive representative Biochem, Germany). Based on dietary levels of organic acids used in previous studies with fish, which range from $0.1 \%$ to $3.0 \%$ [11-18], level of BioAcid Ultra $(0.1 \%$ and $0.2 \%)$ in two treatments were evaluated. Two experimental diets were prepared by supplementing the basal diet with $0.1 \%$ (T1) and $0.2 \%$ (T2) BioAcid Ultra. Pellets are maintained in the refrigerator at $4^{\circ} \mathrm{C}$ until use.

\section{Fish and experimental condition}

Water quality parameters such as temperature and dissolved oxygen were measured daily by Thermometer and oxygen meter (Model WTW320I), respectively. They were kept under optimal range.

Nine hundred rainbow trout fingerlings (average weight $10 \pm 0 / 05$ g) were purchased from Private detective propagation and rearing of salmon (Lorestan, Iran). In this study, 9 Concrete pools $(0.8 \times 4 \times 2 \mathrm{~m})$ were designed. Two feeding treatments (T1 and T2) and one pool as control were conducted as follows:

Control $=$ basal diet (no BioAcid Ultra).

Treatment $1(T 1)=$ basal diet $+0.1 \%$ BioAcid Ultra and

Treatment $(T 2)=$ basal diet $+0.2 \%$ BioAcid Ultra .

Three replicates were maintained for each treatment. Each pool was connected to a flow-through water system. After an initial 14 days acclimation period, fingerlings were randomly distributed in pools (100 fingerlings per pool).

Fingerlings were fed based on their body weight and temperature 4 times $(06: 00,12: 00,18: 00$ and $24: 00)$ a day at $3 \%$ of body weight [19], for a period of 60 days.

\section{Growth Performance and survival rate}

Growth performance, weight and length of Fish (20 fish per pool) was monitored once every 15 days following a 12-h starvation until the end of experiment. Growth performance and survival rate of the fingerlings rainbow trout were calculated using the following Formula [20,21].

$$
\begin{aligned}
& F C R(\text { Feed conversion ratio })=F /(B t-B 0) ; \\
& S G R \% d-1(\text { Specific growth rate })=(\text { Ln Wt }- \text { Ln W0 }) \times 100 / t ;
\end{aligned}
$$

\begin{tabular}{|c|c|c|c|}
\hline Ingredient (\%) & Basal diet & T1 & T2 \\
\hline Fishmeal & 50 & 50 & 50 \\
\hline Soybean meal & 20 & 20 & 20 \\
\hline Wheat flour & 12 & 12 & 12 \\
\hline Fish oil & 10 & 10 & 10 \\
\hline Vitamin premix & 2 & 2 & 2 \\
\hline Mineral premix & 1.5 & 1.5 & 1.5 \\
\hline Filler & 4.5 & 4.5 & 4.5 \\
\hline Proximate composition (\% wet weight) & & & \\
\hline Crud protein & 44.00 & 44.10 & 44.13 \\
\hline Lipid & 13.00 & 13.53 & 13.41 \\
\hline Moisture & 11.00 & 11.00 & 11.00 \\
\hline Ash & 13.00 & 13.48 & 13.78 \\
\hline
\end{tabular}

aContains (mg/kg food): E (30), K (3), niacin (40), thiamine (2), riboflavin (7), pyridoxine (3), folacin (1.5), pantothenic acid (18), biotin (0.7) and cyanocobalamin (0.18).

${ }^{b}$ Contains (mg/kg food): Mg (100), Zn (60), Fe (40), Cu (5), Co (0.1), I (1) and Antioxidant (100)

Table 1: Ingredient and proximate composition of basal diet and experimental diets.

$$
\begin{aligned}
& C F \text { or } K(\text { Condition factor })=100 \times\left(W t / T L^{3}\right) ; \\
& G B M(\text { Gain of body mass })=W t-W 0 ; \\
& \text { Survival rate }=100 \times(N t / N 0) .
\end{aligned}
$$

Where: F: relative food intake (g), Bt and B0: final and initial fish biomass (g); Wt and W0: final and initial body weight (g); t: time of rearing (days); TL: total length; $\mathrm{Nt}$ and N0: final and initial fish number.

\section{Blood sampling}

After a 60-day rearing period, five fish from each treatment (three from each tank) were quickly anesthetized using Clove powder (200 $\mathrm{mg} / \mathrm{l}$ ) then body surface of fingerlings rainbow trout were cleaned with blotting paper to avoid any contamination. Blood was collected using a hypodermic syringe from the caudal blood vessels [22]. The blood samples were transferred to heparinized tubes for hematological parameters and non-heparinized tubes to obtain serum for biochemical parameters. The blood was centrifuged at $3,000 \mathrm{rpm}$ for $10 \mathrm{~min}$ at $4^{\circ} \mathrm{C}$ based on Pradhan et al. [23] and Nelson and Somogyi [24]. The collected plasma and serum were stored at $-70^{\circ} \mathrm{C}$ for further analyses.

\section{Hematological parameters}

Red blood cells (RBCs) and white blood cells (WBCs) were counted under a light microscope using a Neubauer hemocytometer with Hayem's solution as the diluting fluid for RBC and Truck's solution for WBC $[23,25]$. The hemoglobin $(\mathrm{Hb})$ concentrationwas analysed following the cyanmethemoglobin method [26]. Hematocrit (Hct) was determined by centrifuging blood in heparinized microhematocrit capillary tubes at 3,500 rpm for $10 \mathrm{~min}$ [27]. The relative numbers of the types (lymphocytes, neutrophils and monocytes) in the stained peripheral blood were recorded [28], and the percentage of each blood type was calculated as the average blood cell type/sum of averages of all types of blood cells $\times 100$ [29].

\section{Serum biochemical factors}

Biochemical indices, including glucose, total protein, albumin, triglyceride and cholesterol in serum were analyzed using commercial kit (Pars Azmun Co. Ltd., Tehran, Iran) and measured by a spectrophotometer (Model WAP-S2000-UV/VIS, Cambridge-UK) following the manufacturer's instructions [24,30]. Globulin levels are calculated by subtracting the amount of albumin from total protein [31].

\section{Enzymatic assays}

Alkaline Phosphatase (ALP), Alanine aminotranferase (ALT) and Asparatate aminotransferase (AST) were assayed using commercial kit (Pars Azmun Co. Ltd., Tehran, Iran) and measured by an autoanalyzer. ALP was measured according to Bessey et al. [32]. ALT and AST were measured according to Huang et al. [33].

\section{Data analysis}

All data are shown as mean \pm SD (standard deviations). Normality of data was tested by Shapiro-Wilk's test. Data were subjected to oneway ANOVA and significant difference between the treatments was determined by Duncan's test. The values of $\mathrm{P}<0 / 05$ were considered significantly different. All analyses were performed using statistical software SPSS (version, 17).

\section{Results}

The growth performance and survival of fingerlings rainbow trout fed diets supplemented with varying levels of dietary BioAcid Ultra 
Citation: Saei MM, Beiranvand K, Taee HM, Nekoubin H (2016) Effects of Different Levels of BioAcid Ultra on Growth Performance, Survival, Hematologichal and Biochemical Parameters of Fingerlings Rainbow Trout (Oncorhynchus mykiss). J Aquac Res Development 7: 455. doi: 10.4172/2155-9546.1000455

Page 3 of 5

is presented in Table 2. There were significant differences $(\mathrm{P}<0.05)$ in growth performance between treatments and control group. No significant difference $(\mathrm{P}>0.05)$ in survival was observed in fish fed different diets for 60 days. Fish that were fed diet supplemented with $0.1 \%$ and $0.2 \%$ Bio Acid (T1 and $\mathrm{T} 2)$ displayed improved $(\mathrm{P}<0.05)$ growth performance, including GBM and SGR. The amount of CF and FCR in the $\mathrm{T} 1$ was significantly higher than the control group $(\mathrm{P}<0.05)$, but there were no significant difference $(\mathrm{P}>0.05)$ between $\mathrm{T} 2$ and control group and between $\mathrm{T} 2$ and $\mathrm{T} 1$ (Table 2).

Effects of different levels of dietary BioAcid Ultra on hematological parameters of fingerlings rainbow trout are presented in Table 2. No significant difference $(\mathrm{P}>0.05)$ in $\mathrm{RBC}$, Hct and $\mathrm{Hb}$ was observed in treatments and control group for 60 days. Although there was significant difference $(\mathrm{P}<0.05)$, in WBC between $\mathrm{T} 1, \mathrm{~T} 2$ and control group (Table 3 ). The percentage of the lymphocytes, neutrophils and monocytes showed no significant changes between treatments and control group (Table 4).

Effects of varying doses of dietary BioAcid Ultra supplementation

\begin{tabular}{|c|c|c|c|c|c|}
\hline & GBM(g) & SGR (\%) & CF (g/cm) & FCR (\%) & Survival (\%) \\
\hline T1 & $82.44 \pm 5.50^{\mathrm{a}}$ & $2.50 \pm 0.12^{\mathrm{a}}$ & $1.06 \pm 0.06^{\mathrm{a}}$ & $0.77 \pm 0.01^{\mathrm{a}}$ & $\begin{array}{c}97.33 \pm \\
2.51^{\mathrm{a}}\end{array}$ \\
\hline T2 & $77.68 \pm 0.03^{\mathrm{a}}$ & $2.4000 \pm 0.02^{\mathrm{a}}$ & $0.99 \pm 0.03^{\mathrm{ab}}$ & $0.79 \pm 0.01^{\mathrm{ab}}$ & $\begin{array}{c}99.00 \pm \\
1.00^{\mathrm{a}}\end{array}$ \\
\hline Control & $65.82 \pm 2.88^{\mathrm{b}}$ & $2.0867 \pm 0.18^{\mathrm{b}}$ & $0.87 \pm 0.09^{\mathrm{b}}$ & $0.84 \pm 0.05^{\mathrm{b}}$ & $\begin{array}{c}98.00 \pm \\
1.73^{\mathrm{a}}\end{array}$ \\
\hline
\end{tabular}

Values with different superscript letters denote significantly different means within each column $(\mathrm{P}<0.05)$

Table 2: Effects of varying doses of dietary BioAcid Ultra on Growth performance and Survival of O. mykiss at the end of feeding trial.

\begin{tabular}{|c|c|c|c|c|}
\hline & RBC $\left({ }^{a} 10^{6} / \mathrm{mm}^{3}\right)$ & WBC $\left({ }^{\mathrm{a}} 10^{3} / \mathrm{mm}^{3}\right)$ & Hct (\%) & $\mathrm{Hb}(\mathrm{g} / \mathrm{dL})$ \\
\hline $\mathrm{T} 1$ & $1.23 \pm 0.09^{a}$ & $8.49 \pm 0.81^{a}$ & $51.50 \pm 9.19^{a}$ & $4.0767 \pm 0.67^{a}$ \\
\hline $\mathrm{T} 2$ & $1.24 \pm 0.24^{a}$ & $9.10 \pm 0.70^{\mathrm{a}}$ & $52.25 \pm 6.01^{a}$ & $4.0667 \pm 0.36^{a}$ \\
\hline Control & $0.92 \pm 0.11^{a}$ & $6.82 \pm 0.02^{b}$ & $41.50 \pm 2.12^{a}$ & $3.9400 \pm 0.14^{a}$ \\
\hline
\end{tabular}

Values with different superscript letters denote significantly different means within each column $(P<0.05)$.

Table 3: Effects of varying doses of dietary BioAcid Ultra on hematological parameters of $O$. mykiss at the end of feeding trial.

\begin{tabular}{|c|c|c|c|}
\hline & Monocytes & Neutrophils & Lymphocytes \\
\hline T1 & $1.50 \pm 0.71^{\mathrm{a}}$ & $3.50 \pm 2.12^{\mathrm{a}}$ & $95.00 \pm 1.41^{\mathrm{a}}$ \\
\hline T2 & $1.00 \pm 1.41^{\mathrm{a}}$ & $1.00 \pm 1.41^{\mathrm{a}}$ & $98.00 \pm 0.00^{\mathrm{a}}$ \\
\hline Control & $1.33 \pm 2.31^{\mathrm{a}}$ & $2.67 \pm 2.31^{\mathrm{a}}$ & $96.00 \pm 4.00^{\mathrm{a}}$ \\
\hline
\end{tabular}

Values with different superscript letters denote significantly different means within each column $(P<0.05)$

Table 4: Effects of varying doses of dietary BioAcid Ultra on the percentage of the lymphocytes, neutrophils and monocytes in O. mykiss at the end of feeding trial. on biochemical blood parameters are shown in Table 4. No significant difference $(\mathrm{P}>0.05)$ in serum Glucose, Triglyceride and total protein was observed in treatments and control group. Fish fed on diet supplemented with $0.1 \%$ and $0.2 \%$ BioAcid Ultra (T1 and T2) showed significantly $(\mathrm{P}<0.05)$ higher Albumin contents. The serum Globulin level was significantly $(\mathrm{P}<0.05)$ decreased in fish fed diets containing $0.1 \%$ BioAcid Ultra. No significant difference $(\mathrm{P}>0.05)$ in serum Globulin was observed in T2 and control group, and in T1 and T2 (Table 5).

Effects of different levels of dietary BioAcid Ultra on enzyme activity of fingerlings rainbow trout are presented in Table 5. There was no significant $(\mathrm{P}>0.05)$ effect in fish fed on diet supplemented with $0.1 \%$ and $0.2 \%$ BioAcid Ultra as compared to control groups (Table 6).

\section{Discussion}

Growth rate is considered as an important index for the determination of economic efficiency of commercial fish culture and is affected by number of factors [34]. Organic acids are of one of them that show beneficial effects in preservation of feed [3-5]. A number of previous studies indicate that a broad range of organic acids, their salts or mixtures of those can improve growth and feed utilization [6-14]. Adding organic acid blend (formic acid and its salts as well as sorbic acid) to the diet of rainbow trout fingerlings significantly improves SGR of the fish when compared to the control [35]. This result is in agrement with our result that organic acids at a $0.1 \%$ dose can improve growth performance in fingerlings rainbow trout. Similary, Baruah et al. [17] suggested the addition of citric acid in diets significantly increased the weight gain (WG) and the SGR of carp juveniles, while it reduced the FCR. Castillo et al. [13] suggested improve growth performance in juvenile red drum may be in part due to an increment in the activity of digestive enzymes, because pepsin activity, pancreatic enzyme activities (trypsin and lipase) and intestinal enzyme activities (leucinaminopeptidase and phosphatases) were higher with the inclusion of organic acids in the diet. However, phytase and organic acid showed no significant effect on growth performance in juvenile yellow catfish (Pelteobagrus fulvidraco) [11]. It seems that effects of organic acids on fish depend on the fish species, type of organic acid and dosage used [6].

Hematological parameters including RBC, WBC (both number and the percentage of Lymphocytes, Neutrophils, Monocytes) Hb, Hct are important factors that could be considered during the fish diet quality, fish conditions and toxic effect of substances assessment [36]. These factors are considered valuable indices to assess fish health [37,38]. Our result revealed that dietary addition of $0.1 \%$ and $0.2 \%$ BioAcid Ultra showed no change on hematological parameters (except WBC ) as well as the percentage of Lymphocytes, Neutrophils and Monocytes, that means adding BioAcid Ultra in dosage $0.1 \%$ and $0.2 \%$ has no effect

\begin{tabular}{|c|c|c|c|c|c|c|}
\hline & Glucose (mg/dl) & Triglyceride (mg/dl) & Cholesterol (mg/dl) & TP (mg/dl) & Albumin (mg/dl) & Globulin (mg/dl) \\
\hline $\mathrm{T} 1$ & $125.00 \pm 49.87^{a}$ & $261.33 \pm 61.72^{\mathrm{a}}$ & $216.67 \pm 23.07^{\mathrm{a}}$ & $5.98 \pm 0.11^{\mathrm{a}}$ & $2.49 \pm 0.41^{\mathrm{a}}$ & $3.49 \pm 0.34^{\mathrm{b}}$ \\
\hline T2 & $110.00 \pm 44.53^{\mathrm{a}}$ & $318.67 \pm 129.10^{\mathrm{a}}$ & $277.67 \pm 7.64^{a}$ & $5.98 \pm 0.04^{a}$ & $2.15 \pm 0.31^{\mathrm{ab}}$ & $3.83 \pm 0.27^{\mathrm{ab}}$ \\
\hline Control & $145.00 \pm 9.54^{a}$ & $312.67 \pm 2.52^{\mathrm{a}}$ & $268.33 \pm 84.69^{a}$ & $5.82 \pm 0.09^{a}$ & $1.60 \pm 0.10^{b}$ & $4.22 \pm 0.17^{\mathrm{a}}$ \\
\hline
\end{tabular}

Table 5: Effects of varying doses of dietary BioAcid Ultra on biochemical blood parameters of $O$. mykiss at the end of feeding trial

\begin{tabular}{|c|c|c|c|}
\hline & ALP (U/L) & ALT (U/L) & AST (U/L) \\
\hline T1 & $596.76 \pm 39.64^{a}$ & $21.67 \pm 4.04^{a}$ & $546.67 \pm 143.85^{a}$ \\
\hline $\mathrm{T} 2$ & $575.60 \pm 18.31^{a}$ & $23.33 \pm 5.51^{a}$ & $486.33 \pm 86.87^{a}$ \\
\hline Control & $603.64 \pm 21.17^{a}$ & $22.33 \pm 4.04^{\mathrm{a}}$ & $570.33 \pm 25.42^{\mathrm{a}}$ \\
\hline
\end{tabular}

Table 6: Effects of varying doses of dietary BioAcid Ultra on enzymatic activity of $O$. mykiss at the end of feeding trial. 
Citation: Saei MM, Beiranvand K, Taee HM, Nekoubin H (2016) Effects of Different Levels of BioAcid Ultra on Growth Performance, Survival, Hematologichal and Biochemical Parameters of Fingerlings Rainbow Trout (Oncorhynchus mykiss). J Aquac Res Development 7: 455. doi: 10.4172/2155-9546.1000455

on health and immune system of rainbow trout fingerlings. Baruah et al. [10] reported a significant increase in $\mathrm{Hb}, \mathrm{Hct}$, while no effect was observed on WBC and RBC counts in rohu juveniles fed on $3 \%$ citric acid and $500 \mathrm{U} / \mathrm{kg}$ phytase. Khajepour et al. [37] revealed that adding $3 \%$ citric acid in diet significantly increased $(\mathrm{P}<0.05) \mathrm{Hb}$ content and Hct values in Beluga. Although, $3 \%$ citric acid showed no effect on RBC and WBC count which reflects that diet acidification does not cause any stress (dietary imbalance) that usually cause an increase in WBCs count [37]. In another study, 3\% citric acid in Red sea bream showed no effect on Hct [39]. On the other hand, $1 \%$ and $2 \%$ citric acid in Red sea bream [40], and 3\% citric acid in Common carp [37] increased Hct. In the case of fingerlings rainbow trout, our results in agreement with the results of Khajepour et al. [37] in Beluga. Similarly in the case of $\mathrm{Hb}$ and Hct, our result in agreement with the results of Sarker et al. [39].

In this study, fish fed dietary $0.1 \%$ and $0.2 \%$ BioAcid Ultra showed no effect on total serum protein, Glucose, Triglyceride and Cholesterol. Similarly, serum glucose and total proteins in Beluga were not affected by citric acid inclusion which indicates that acidification does not cause any metabolic stress [37]. However, Baruah et al. [10] reported significant increases in total protein, albumin and globulin values were observed in rohu juveniles fed on $3 \%$ citric acid and $500 \mathrm{U} / \mathrm{kg}$ phytase. on the other hand in present study Globulin and albumin decreased and increased in T1, resspectively. Similar results have been reported by Baruah et al. [10] that $3 \%$ citric acid increased albumin in rohu juveniles.

Bitiren et al. [41] indicated that significant increase in the activities of serum ALP, AST and ALT are considered as the response of organism to stressors. Our data show that fish fed dietary BioAcid Ultra had no effect on ALP, ALT and AST of fingerlings rainbow trout. Therefore, we can state that fish could tolerate the addition of $0.1 \%$ and $0.2 \%$ BioAcid Ultra without any deleterious effects on fish. These results are in full agreement with those of El-Kerdawy [42]. In another study, Ashouri et al. [43] indicated the activity of ALT was significantly higher in fish fed on $2 \mathrm{mg}$ nano-Se/kg; but no significant differences were found in serum ALP activity among the experimental groups. In the present study, similar results of using BioAcid Ultra in Rainbow trout to other studies were found. Therefore, there are many beneficial effects of using organic acids in fish performance, but there are also reports in which no effect was found.

\section{Conclusion}

In conclusion, Observed difference in different studies indicates differences in fish species, sources and levels of organic acids in response to organic acids. In the present study, the best performance of fish in terms of growth performance in fingerlings rainbow trout, was recorded at organic acids at a $0.1 \%$ dose without any deleterious or stressor effects on fish.

\section{Acknowledgment}

The authors would like to thank Aria Dalman for providing the necessary facilities for the study.

\section{References}

1. Girri SS, Sahoo K, Sahu BB, Sahu AK, Mohanty SN, et al. (2002) Dietary modulation of the human colonic microbiota: Introducing the concept of prebiotics. Journal of Nutrition 125: 1401-1412.

2. NRC (National Research Council) (2011) Nutrient requirements of fish. National Academy of Science, Washington, DC.

3. Luckstadt C (2006) Use of organic acids as feed additives sustainable aquaculture production the non-antibiotic way. International Aquafeed 9: 21-26.
4. Atapattu NSBM, Senevirathne TSMS (2013) Effects of increasing levels of dietary cooked and uncooked banana meal on growth performance and carcass parameters of broiler chicken. Pakistan veterinary 33: 179-182.

5. Sing KW, Kamarudin MS, Wilson JJ, Azirun MS (2014) Evaluation of blowfly (Chrysomya megacephala) maggot meal as an effective, sustainable replacement for fishmeal in the diet of farmed juvenile red tilapia (Oreochromis sp.). Pakistan veterinary $34: 288-292$.

6. Luckstadt C (2008) The use of acidifiers in fish nutrition. CAB Reviews: Perspectives in Agriculture, Veterinary Science, Nutrition and Natural Resources 3: 1-8.

7. Luckstadt C (2007) Effect of organic acid containing additives in worldwide aquaculture-Sustainable production the non-antibiotic way. Acidifiers in animal nutrition-A guide for feed preservation and acidification to promote animal performance. (1stedn). Nottingham University Press, Nottingham, UK.

8. Pandey A, Satoh S (2008) Effects of organic acids on growth and phosphorus utilization in rainbow trout (Oncorhynchus mykiss). Fisheries Science 74: 867-874.

9. Ng WK, Koh CB, Sudesh K, Siti-Zahrah A (2009) Effects of dietary organic acids on growth, nutrient digestibility and gut micro flora of red hybrid tilapia (Oreochromis sp.) and subsequent survival duringduring a challenge test with Streptococcus agalactiae. Aquaculture Research 40: 1490-1500.

10. Baruah K, Pal AK, Sahu NP, Debnath D, Yengkokpam S, et al. (2009) Dietary crude protein, citric acid and microbial phytase interacts to influence the hemato-immunological parameters of rohu (Labeo rohita), juveniles. Journal of the World Aquaculure Society 40: 824-831.

11. Zhu Y, Qiu X, Ding Q, Duan M, Wang CH (2011) Combined effects of dietary phytase and organic acid on growth and phosphorus utilization of juvenile yellow catfish (Pelteobagrus fulvidraco). Aquaculture 321: 245-251.

12. Khajepour F, Hosseini SA (2012) Citric acid improves growth performance and phoshorus digestibility in Beluga (Huso huso) fed diets where soybean meal partly replaced fish meal. Animal Feed Science Technology 171: 68-73.

13. Castillo S, Rosales M, Pohlenz C, Gatlin DM (2014) Effects of organic acids on growth performance and digestive enzyme activities of juvenile red drum (Sciaenops ocellatus). Aquaculture 433: 6-12.

14. Freitag $M$ (2007) Organic acids and salts promote performance and health in animal husbandry. In: Luckstadt, C. (Ed). Acidifiers in animal nutrition-A guide for feed preservation and acidification to promote animal performance. (1stedn). Nottingham University Press, Nottingham, UK.

15. Mroz Z, Krasucki W, Grela E, Matras J, Eidelsburger U (2000) The effects of propionic and formic acids as blend (Lupro-Cid) in graded dosages on the health, performance and nutrient digestibility (ileal/overall) in sows. Proceedings of the Society of Nutrition Physiology 9: 72.

16. Øverland M, Granli T, Kjos NP, Fjetland O, Steien SH, et al. (2000) Effect of dietary formats on growth performance, carcass traits, sensory quality, intestinal microflora, and stomach alterations in growing-finishing pigs. Journal of Animal Science 78: 1875-1884.

17. Baruah K, Sahu NP, Pal AK, Jain KK, Debnath D, et al. (2007) Dietary microbial phytase and citric acid synergistically enhances nutrient digestibility and growth performance of Labeo rohita (Hamilton) juveniles at suboptimal protein level. Aquaculture 38: 109-120.

18. Hossain MA, Pandey A, Satoh S (2007) Effects of organic acids on growth and phosphorus utilization in red sea bream (Pagrus major). Fisheries Science 73 1309-1317.

19. FAO (Food and Agriculture Organization) (2016) Table of an example of a feeding table for Atlantic salmon (\% body weight/day). Food and Agriculture Organization of the United Nations, Rome, Italy.

20. Ronyai A, Peteri A, Radics F (1990) Cross breeding of starlet and lena river sturgeon. Aquaculture 6: 13-18.

21. Hung SSO, Lutes PB, Storebakken T (1989) Growth and feed efficiency of whitesturgeon (Acipenser transmontanus) sub yearling at different feeding rates. Aquaculture 80: 147-153.

22. Trenzado CE, Carrick RT, Pottinger TG (2003) Divergence of endocrine and metabolic responses to stress in two rainbow trout lines selected for differing cortisol responsiveness to stress. General and Comparative Endocrinology 133: 332-340.

23. Pradhan SC, Patra AK, Sarkar B, Pal A (2012) Seasonal changes in 
Citation: Saei MM, Beiranvand K, Taee HM, Nekoubin H (2016) Effects of Different Levels of BioAcid Ultra on Growth Performance, Survival, Hematologichal and Biochemical Parameters of Fingerlings Rainbow Trout (Oncorhynchus mykiss). J Aquac Res Development 7: 455. doi: 10.4172/2155-9546.1000455

Page 5 of 5

hematological parameters of Catla catla (Hamilton 1822). Comparative Clinical Pathology 21:1473-1481.

24. Nelson JW, Somogyi M (1945) Determination of glucose. Hawk's physiological chemistry, (14thedn). McGraw Hill Publication, New York.

25. Pradhan SC, Patra AK, Pal A (2014) Hematological and plasma chemistry of Indian major carp, Labeo rohita (Hamilton, 1822). Journal of Applied Ichthyology 30: 48-54.

26. Akhtar MS, Pal AK, Sahu NP, Ciji A, Mahanta PC (2013) Thermal tolerance oxygen consumption and haemato-biochemical variables of Tor putitora juveniles acclimated to five temperatures. Fish physiology and biochemistry 39: $1387-1398$

27. Blaxhall PC, Daisley KW (1973) Routine haematological methods for use with fish blood. Journal of Fish Biology 5: 771-781.

28. Zexia G, Weimin WYIY, Abbas K, Dapeng L, Guiwei Z, et al. (2007) Morphological studies of peripheral blood cells of the Chinese sturgeon (Acipenser sinensis). Fish physiology and biochemistry 33: 213-222.

29. Burgos-Aceves MA, Campos-Ramos R, Guerrero-Tortolero DA (2010) Description of peripheral blood cells and differential blood analysis of captive female and male leopard grouper (Mycteroperca rosacea) as an approach for diagnosing diseases. Fish physiology and biochemistry 36: 1263-1269.

30. Benfey TJ, Biron M (2000) Acut estress response in triploid rainbow trout (Oncorhynchus mykiss) and brook trout (Salvelinus fontinalis). Aquaculture 184: 167-176.

31. Kumar S, Sahu NP, Pal AK, Choudhury D, Yengkokpam S, et al. (2005) Effect of dietary carbohydrate on haematology, respiratory burst activity and histological changes in Labeo rohita juveniles. Journal of Fish and Shellfish Immunology 19: 331-344.

32. Bessey OA, Lowry OH, Brock MJ (1946) Rapid coloric method for determination of alkaline phosphatase in five cubic millimeters of serum. Journal of Biological Chemistry 164: 321-329.

33. Huang XJ, Choi YK, Im HS, Yarimaga O, Yoon E, et al. (2000) Aspartate
Aminotransferase (AST/GOT) and Alanine Aminotransferase (ALT/GPT) detection techniques. Sensors (Basel) 6: 756-782.

34. Shah SZH, Afzal M, Yar Khan SH, Hussain SM, Habib RZ (2015) Prospects of using citric acid as fish feed supplement. International Journal of Agriculture and Biology 17: 1-8.

35. De Wet L (2005) Organic acids as performance enhancers. Journal of Aquaculture Feeds: Formulation \& Beyond 2: 12-14.

36. Svobodova Z, Fravda D, Palakova J (1991) Unified methods of haematological examination of fish. Research Institute of Fish Culture and Hydrobiology 1991 VURH Vodnany, Edice Metodik, Czechoslovakia.

37. Khajepour F, Hosseini SA, MaHoseini S (2011) Studyon some hematological and biochemical parameters of juvenile beluga (Huso huso) fed citric acid supplemented diet. Global Veterinaria 7: 361-364.

38. Roberts R, Rodger H (1978) The pathophysiology and systematic pathology of teleosts. Fish Pathology 62-143.

39. Sarker MSA, Satoh S, Kiron V (2005) Supplementation of citric acid and amino acid-chelated trace element to develop environment-friendly feed for red sea bream (Pagrus major). Aquaculture 248: 3-11.

40. Sarker MSA, Satoh S, Kiron V (2007) Inclusion of citric acid and/or amino acid chelated trace elements in alternate plant protein source diets affects growth and excretion of nitrogen and phosphorus in red sea bream (Pagrus major). Aquaculture 262: 436-443.

41. Bitiren M, Karak'lç'k AZ, Zerin M, Aksoy N, Musa D (2004) Effects of selenium on histopathological and enzymatic changes in experimental liver injury of rats. Experimental and Toxicologic Pathology 56: 59-64.

42. El-Kerdawy DMA (1996) Acidified feed for growing rabbits. Egyptian Journal of Rabbit Science 6: 143-156.

43. Ashouri S, Keyvanshokooh S, ParvizSalati A, Johari SA, Pasha-Zanoosi H (2015) Effects of different levels of dietary selenium nano particles on growth performance, muscle composition, blood biochemical profiles and antioxidan status of common carp (Cyprinus carpio). Aquaculture 446: 25-29. 